\title{
MANAJEMEN KEUANGAN YAYASAN MASJID AL-MAGHFIRAH SURABAYA TAHUN 2016
}

\author{
Ahmad Syauqi \\ STID Al-Hadid, Surabaya \\ syauqi@gmail.com
}

\begin{abstract}
Abstrak: Masjid, sebagai lembaga nirlaba memiliki potensi sumber dana yang besar yang dapat dikelola untuk kegiatan dakwah. Namun dalam pelaksanaannya, masih banyak masjid yang pengelolaan keuangannya yang seadanya dan belum teradministrasi dengan baik mulai dari rencana anggaran sampai pada pelaporan. Di sisi lain, ada masjid yang pengelolaan keuangannya/manajemen keuangannya teratur/baik, yaitu Masjid Al-Maghfirah Surabaya, hingga dinobatkan sebagai masjid percontohan administrasi oleh Dewan Masjid Indonesia (DMI) Tingkat Jatim, salah satu penilaiannya berdasarkan pengelolaan keuangan. Tulisan ini mendeskripsikan manajemen keuangan Masjid Al-Maghfirah Surabaya, menggunakan teori "Manajemen Keuangan Organisasi Pengelola Zakat" dari Hertanto Widodo dan Teten Kustiwana yang terdiri dari perencanaan pengelolaan dan pengendalian. Pendekatannya kualitatif deskriptif, sumber data diperoleh dari wawancara dengan pengurus masjid, observasi kegiatan, dan dokumen keuangan masjid. Teknik analisis datanya adalah data reduction, data display, dan conclusion drawing/verification. Pengujian menggunakan perpanjangan pengamatan, bahan referensi, member check, dan triangulasi. Hasil penelitian menunjukkan bahwa Masjid Al-Maghfirah Surabaya, dalam memanajemen keuangan, membuat perencanaan untuk masa waktu satu tahun. Dalam pengelolaannya, dana yang diterima oleh masjid dikelola dalam empat rekening. Pengendalian keuangan masjid dengan melakukan pencatatan, dan pelaporan setiap tiga bulan sekali. Laporan dipublikasikan melalui majalah Al-Maghfirah..
\end{abstract}

Kata kunci: manajemen/pengelolaan keuangan, Masjid Al-Maghfirah, keuangan masjid

\begin{abstract}
A mosque, as a non-profit institution, owns enormous potential of fund source which can be managed for da'wah activities. However, there are a lot of mosques whose implementations of financial managements are unprofessional. The process from budgetting to financial reporting has not been administered well. Among the mosques, there is a mosque whose financial management has been managed in a good standard. It is the mosque of Al-Maghfiroh Surabaya. It was awarded as a mosque with administrative model by Dewan Masjid Indonesia (Indonesian Mosque Council) - East Java. One of the appraisals was based on financial management. This study describes financial management of the mosque of Al-Maghfirah - Surabaya, by applying the theory of "Manajemen Keuangan Organisasi Pengelola Zakat" / "Financial Management of Zakah-organizing institution" by Hertanto Widodo and Teten Kustiwana, consisting of planning of management and controlling. Its approach is descriptive qualitiative. Its data source taken from interviewing with mosque committees, observing activities, and financial documents of the mosque. Its technique of data analysis is data reduction, data display and concludion drawaing / verification. The testing uses in-dept observation,
\end{abstract}


references, member check and triangulation. The result of the research shows that the msoque of Al-Maghfiroh - Surabaya, in financial management, has made a planning for a year. In its management, received fund is managed in four accounts. Its financial controlling is conducted by recording and reporting every three months. The report is published in the magazine of Al-Maghfirah.

Key words: financial management, the Mosque of Al-Maghfirah, finance of mosque

\section{Pendahuluan}

Pengurus masjid sebagai bagian dari organisasi kemasyarakatan berperan mengelola program-program dakwah dalam masjid seperti ibadah salat, pengajian, dan sebagainya. Untuk menjalankan programprogram dakwah tersebut memerlukan sumber daya yang salah satunya adalah dana. Dana berperan penting terhadap kesuksesan program-program dakwah, karena menjadi resource untuk membeli kebutuhan-kebutuhan program. Berdasarkan Undang-Undang tentang Yayasan, masjid berada di bawah lembaga berbentuk yayasan memiliki kekayaan yang berasal dari sumbangan dan bantuan tidak mengikat, wakaf, hibah, hibah wasiat dan perolehan lain yang tidak bertentangan dengan anggaran dasar yayasan dan/atau peraturan perundang-undangan yang berlaku. $^{1}$ Dalam praktiknya dana masjid berasal dari sumbangan ataupun Zakat, Infak, Sedekah (ZIS) para jemaah masjid yang melaksanakan ibadah di masjid tersebut.

Banyak fungsi masjid dalam pengadaan aktivitas dakwah seperti tempat kaum muslimin beribadah dan mendekatkan diri kepada Allah SWT., tempat kaum muslimin beriktikaf, menggembleng batin untuk

\footnotetext{
1 Undang-Undang Republik Indonesia Nomor 16 Tahun 2001 tentang Yayasan, Pasal 37 ayat 1.

2 Mohammad E. Ayub, Manajemen Masjid, (Jakarta, Gema Insani Press, 1996), 7-8.
}

membina kesadaran dan mendapatkan pengalaman batin/keagamaan sehingga selalu terpelihara keseimbangan jiwa dan raga serta keutuhan kepribadian, tempat bermusyawarah kaum muslimin guna memecahkan persoalan-persoalan yang timbul di masyarakat, dan seterusnya. ${ }^{2}$ Masjid sebagai sentral kegiatan dakwah juga memiliki potensi sumber dana yang sangat besar dari Umat Islam yang merupakan mayoritas masyarakat Indonesia, Umat Islam memiliki kebutuhan/kewajiban setidaknya menyalurkan 2,5\% hartanya setiap tahun yang berbentuk zakat dan berdasarkan data Badan Amil Zakat Nasional (BAZNAS) menyatakan bahwa pada tahun 2016 total dana zakat umat Islam di Indonesia sebesar Rp. 5.017.293.126.950. ${ }^{3}$ Hal ini menunjukan bahwa sangat besarnya potensi dana pada masjid yang seharusnya dapat dikelola dan dipotensikan dengan baik.

Masjid memiliki tanggungjawab besar dalam mengelola, memberdayakan dan mengalokasikan dana tersebut secara optimal demi terlaksananya programprogram dakwah dalam rangka mewujudkan visi misi yayasan masjid. Di sisi lain mengelola dana yang bersumber dari para jemaah masjid dengan baik merupakan tanggung jawab moral pengurus masjid agar

\footnotetext{
${ }^{3}$ Badan Amil Zakat Nasional, "Statistik Zakat Nasional Tahun 2016," baznas.go.id. diakses 12 September 2018, https://pid.baznas.go.id/wp-content/szn/SZN2016.pdf
} 
pengurus masjid tetap mendapat kepercayaan oleh Jemaah untuk mengelola dana mereka.

Keadaan tersebut menuntut para pengurus masjid melakukan manajemen keuangan dengan tepat. Ketidakmampuan dalam mengelola dana masjid berdampak pada mulai dari pengeluaran dana yang tidak efisien, pembengkakan anggaran, pengeluaran tidak tepat sasaran, rawan terjadi penyalahgunaan dana, dan sebagainya. Keadaan-keadaan seperti ini bila terjadi selain dapat menghambat kegiatan-kegiatan dakwah juga dapat menurunkan kredibilitas dan integritas pengurus masjid di mata para jemaah yang sebelumnya mempercayakan dananya untuk dikelola pengurus masjid. Rasa kecewa yang dimiliki oleh jemaah atas masalah pengelolahan dana pada masjid akan sukar untuk dihilangkan. Nama baik yang telah tercoreng di mata publik akan sangat merugikan masjid karena pasti berimplikasi pada penurunan penerimaan dana dari jemaah yang akhirnya menyulitkan pelaksanaan program dakwah yang direncanakan.

Manajemen keuangan masjid menurut Ayub, Muhsin, \& Mardjoned terbagi menjadi tiga bagian utama, yaitu anggaran masjid, sumber dana masjid, dan laporan keuangan masjid. ${ }^{4}$ Salah satu ciri manajemen keuangan yang baik adalah adanya transparansi dan akuntabilitas dalam pengelolahan keuangan. Prinsip transparansi dan akuntabilitas dalam pengelolahan dana yang diserap oleh masjid tercermin dari laporan keuangan masjid yang transparan dan akuntabel. ${ }^{5}$ Masjid merupakan bagian dari organisasi nirlaba, maka standar akuntansi yang berlaku umum bagi organisasi nirlaba di Indonesia yaitu PSAK 45. ${ }^{6}$ Namun pada praktiknya manajemen keuangan masjid masih memiliki kekurangan. Hal ini ditunjukan dari hasil penelitian yang pernah dilakukan oleh Jerry Aulia Assadul Haq dan Miranti Kartika Dewi tentang manajemen keuangan yang salah satunya mengungkap tentang elemen anggaran dalam masjid. Dari tiga sampel masjid yang diteliti, antara lain:

Tabel 1 - Praktik Pelaporan Keuangan Beberapa Masjid Kota $X^{7}$

\begin{tabular}{c|c|c|c|c}
\hline No & Nama Masjid & $\begin{array}{c}\text { Model Pencatatan yang } \\
\text { Digunakan }\end{array}$ & Penggunaan PSAK 45 & $\begin{array}{c}\text { Laporan Keuangan } \\
\text { yang Diaudit }\end{array}$ \\
\hline \hline 1 & Masjid Besar A & Single-Entry & Tidak & Tidak \\
2 & Masjid Jami B & Single-Entry & Tidak & Tidak \\
3 & Masjid C & Single-Entry & Tidak & Tidak \\
\hline
\end{tabular}

Berdasarkan data penelitian tersebut dapat dilihat bahwa beberapa masjid masih belum

\footnotetext{
4 Jerry Aulia Assadul Haq dan Miranti Kartika Dewi, "Praktik Manajemen Keuangan Masjid dan Potensi Dana Masjid (Studi Kasus Pada Beberapa Masjid di Kota X)," (Accounting Departement, Faculty of Economic, University of Indonesia, 2013), 4.

5 Ibid., 2.
}

menerapkan standar keuangan organisasi nirlaba dalam pengelolahan dananya. Selain

\footnotetext{
6 PSAK kepanjangan dari Pernyataan Standar Akuntansi Keuangan. Ikatan Akuntansi Indonesia menerbitkan PSAK Nomor 45 tentang Pelaporan Keuangan Organisasi Nirlaba.

${ }^{7}$ Haq dan Dewi, "Praktik Manajemen." 9-10.
} 
itu masih banyak masjid yang laporan keuangannya belum sempat dilakukan audit. Ini menunjukan masih ada kelemahan pengelolahan keuangan masjid dari segi pengendalian yang nantinya akan mempersulit pengurus masjid dalam mengambil keputusan strategis dan juga menurunkan kepercayaan jemaah masjid terhadap proses pengelolaan keuangan yang transparan dan akuntabilitas. Hal ini menjadi catatan penting untuk diatasi dikarenakan kegiatan dakwah membutuhkan sumber daya dana. Apalagi jumlah masjid di Indonesia sangat banyak, yakni terdapat 800.000 masjid. Hal itu diutarakan oleh H. M. Jusuf Kalla selaku Ketua Umum Dewan Masjid Indonesia. ${ }^{8}$

Di antara masjid-masjid yang sudah berdiri di Indonesia, beberapa masjid sudah mulai menerapkan pengelolaan keuangan yang profesional. Salah satu masjid tersebut adalah Masjid Al-Maghfirah Surabaya, yang berdiri sejak tahun 1988. Awal kali didirikan pengurus masjid langsung mendaftarkan kepengurusan Masjid Al-Maghfirah dalam bentuk yayasan. Hal ini ditunjukkan dengan adanya akte pendirian dan Surat Keputusan (SK) Menteri Hukum \& HAM. Masjid AlMaghfirah memiliki prestasi yang patut untuk diapresiasi, yakni penghargaan yang diberikan dari Dewan Masjid Indonesia (DMI) Pengurus Wilayah Pemerintah Provinsi Jawa Timur sebagai masjid percontohan bidang administrasi. Beberapa hal yang membuat Masjid Al-Maghfirah diberikan penghargaan tersebut diantaranya adalah adanya pemberian SK ketika pengangkatan setiap orang yang menjadi pengurus. Selain itu adalah adanya

\footnotetext{
8 Ihsanuddin, "Raja Salman Terkejut Indonesia Punya 800.000 Masjid" Kompas.com, diakses 12 September 2018, https://nasional.kompas.com/read/2017/03/04/1214
}

sistem empat rekening yang dikelola masjid dengan sumber pemasukan dan peruntukan dana yang berbeda-beda. Sehingga penggunaan dana tersebut sesuai dengan perencanaan dan niat dari jemaah yang memberikannya. Hal ini sangat menarik dan penting untuk dikaji lebih mendalam, mengingat keadaan pengelolaan keuangan di masjid-masjid lain yang masih di bawah standar dan hanya mengandalkan aspek kepercayaan saja dari jemaah. Studi ini bertujuan untuk mendeskripsikan penerapan manajemen keuangan pada Yayasan Masjid Al-Maghfirah. Manfaatnya antara lain memperkaya khazanah ilmu pengetahuan berkenaan dengan teori manajemen keuangan pada masjid dan sebagai bahan referensi bagi pengurus masjid-masjid lainnya dalam merencanakan dan menerapkan pengelolaan keuangan pada masjid.

Dalam studi ini, kajian teoritis yang menjadi alat untuk mengurai dan menganalisis manajemen keuangan pada Yayasan Masjid Al-Maghfirah Surabaya adalah teori akuntansi dan manajemen keuangan pengelola zakat yang dicetuskan oleh Hertanto Widodo dan Teten Kustiwana. Teori ini pun telah menjadi rujukan pada penelitian-penelitian organisasi nirlaba sebelumnya yakni pada Skripsi Sri Indah Mulyati Tanjung, Mahasiswa Universitas Islam Negeri (UIN) Syarif Hidayatullah Jakarta. Dengan judul "Tinjauan Ekonomi Islam Terhadap Manajemen Keuangan Lembaga Amil Zakat (LAZ) Al-azhar "Peduli Ummat" dalam Mengelola Dana Zakat, Infak dan Shadaqah (ZIS)." Penelitian tersebut mengambil Lembaga Amil Zakat Al-Azhar

4741/raja.salman.terkejut.indonesia.punya.800.000. $\underline{\text { masjid }}$ 
"Peduli Umat" sebagai subjek penelitian yang dikaji. ${ }^{9}$ Penelitian selanjutnya adalah penelitian Sochimin dari Institut Agama Islam (IAIN) Purwokerto dengan judul "Praktik Manajemen Keuangan Masjid Berbasis Pemberdayaan Ekonomi Umat di Kota Purwokerto." ${ }^{10}$ Selanjutnya adalah penelitian yang dilakukan oleh Jerry Aulia Assadul Haq dan Miranti Kartika dewi dari Universitas Indonesia dengan Judul "Praktik Manajemen Keuangan Masjid dan Potensi Dana Masjid (Studi Kasus Pada Beberapa Masjid di Kota X)." Adapun persamaan penelitian tersebut dengan studi ini ialah pada aspek objek penelitiannya yakni mengamati pengelolaan dana pada kepengurusan masjid. ${ }^{11}$ Sehingga dengan berbedanya riset kali ini dengan penelitian sebelumnya, diharapankan dapat memperkaya pengetahuan tentang pengelolaan dana pada lembaga dakwah yang sudah ada.

Tulisan ini menggunakan pendekatan kualitatif deskriptif, sumber datanya dari wawancara pengurus Yayasan Masjid AlMaghfirah Surabaya, beberapa pihak yang menjadi narasumber yaitu $\mathrm{H}$. Sudiro selaku Ketua Dewan Pengurus, H. Rachmat Bhakti selaku Sekertaris Dewan Pengurus, dan H. Tarmidjan HW selaku Bendahara. Dilakukan pula observasi dengan mengikuti kegiatan masjid yang berjalan, dan dokumentasi proses pengelolaan dana. Observasi penelitian dilakukan dalam jangka waktu dua bulan empat hari terhitung mulai dari 10 Oktober 2016 sampai dengan 14 Desember

9 Sri Indra Mulyati Tanjung, "Tinjauan Ekonomi Islam Terhadap Manajemen Keuangan Lembaga Amil Zakat (LAZ) Al-Azhar Peduli Ummat dalam Mengelola Dana Zakat, Infak dan Shadaqah (ZIS)," (Skripsi, Universitas Islam Negeri Syarifudin Hidayatullah, 2005), 76. 10 Sochimin, "Praktik Manajemen Keuangan Masjid Berbasis Pemberdayaan Ekonomi Umat di Kota
2016. Analisisnya menggunakan data reduction (reduksi data), data display (penyajian data), conclucion drawing/verivication. Keabsahan data diuji dengan perpanjangan pengamatan, menggunakan bahan referensi, mengadakan membercheck dan melakukan triangulasi data antara antar sesama pengurus dan dokumen yang dimiliki oleh masjid.

\section{Akuntansi dan Manajemen Keuangan Pengelola Zakat}

Teori akuntansi dan manajemen keuangan pengelola zakat oleh Hertanto Widodo dan Teten Kustiwana dipilih, mengingat bahwa Yayasan Masjid Al-Maghfirah merupakan organisasi nirlaba yang berlandaskan keagamaan. Organisasi nirlaba keagamaan adalah organisasi nonprofit yang bergerak dibidang keagamaan misalnya gereja, masjid, lembaga-lembaga pekabaran injil, lembaga-lembaga misi islam dan sebagainya. ${ }^{12}$ sehingga akan lebih sesuai menggunakan pijakan teori manajemen keuangan nirlaba, karena organisasi laba dan nirlaba memiliki karakteristik yang sangat jauh berbeda. Selain teori ini dapat diperuntukkan bagi organisasi pengelolaan dana dalam agama Islam. hal ini sangat cocok dengan karakteristik Yayasan Masjid Al-Maghfirah yang juga memiliki dasar agama Islam, ditambah teori ini sudah pernah dipergunakan dalam penelitian

Purwokerto," (Penelitian Individual, Institut Agama Islam Negeri Purwokerto, 2015), 123.

11 Haq dan Dewi, Praktik Manajemen., 10.

12 Merystika Kabuhung, "Sistem Informasi Akutansi Penerimaan dan Pengeluaran Kas Untuk Perencanaan dan Pengendalian Keuangan Pada Organisasi Nirlaba Keagamaan," Jurnal EMBA Vol 1, No 3 (2013): 343. 
masjid yang selainnya sehingga sangat dapat diaplikasikan.

Dalam akuntansi \& manajemen keuangan pengelola zakat terdapat tiga variabel utama dalam melakukan pengelolaan sumber daya dana yakni adanya variabel perencanaan, pengelolaan, dan pengendalian atau pengawasan.

\section{Perencanaan Keuangan}

Membuat perencanaan atau menyusun rencana kegiatan dan anggaran tahunan (RKAT) atau budgeting yang meliputi berapa dana yang diharapkan terhimpun beserta sumber dan strategi memperolehnya, berapa jumlah dana yang akan disalurkan, dan jumlah orang atau lembaga yang akan menerimanya, serta saldo minimum yang harus tersedia sebagai cadangan untuk paling tidak- setiap bulannya. Perencanaan keuangan pada umumnya diwujudkan dalam bentuk anggaran (budget). Anggaran adalah suatu rencana yang disusun secara sistematis, yang meliputi seluruh kegiatan organisasi yang dinyatakan dalam unit (kesatuan) moneter dan berlaku untuk jangka waktu (periode) tertentu yang akan datang.

Untuk pengelolaan zakat, anggaran yang paling penting terkait dengan pengelolaan keuangan adalah anggaran kas. Hal ini didasarkan atas pertimbangan bahwa tugas pokok pengelola zakat ditinjau dari aliran dana yakni penghimpunan dan penyaluran dana.

Pada dasarnya anggaran kas pengelolaan zakat dapat dibagi dalam dua bagian. Pertama, anggaran penghimpunan, yaitu proyeksi jumlah kas yang akan diterima yang berasal dari zakat, infak-sedekah, dan sumber dana lainnya. Kedua, anggaran penyaluran, yaitu estimasi penyaluran dana untuk para mustahiq dalam berbagai bentuk program serta biaya operasional pengelolaan zakat.

\section{Pengelolaan Keuangan}

Membuat panduan berupa kebijakan umum dan petunjuk teknis terkait dengan pengelolaan dana yang akan dilaksanakan di lembaga. Panduan ini harus mencakup penghimpunan, penyaluran, dan saldo dana. Pertama, penghimpunan dana. Panduan dalam penghimpunan dana mencakup tentang jenis dana dan cara dana diterima. Organisasi pengelola harus menetapkan jenis dana yang akan diterima sebagai sumber dana. Setiap jenis dana memiliki karakteristik dan konsekuensi pembatasan berbeda yang harus dipenuhi oleh pengelola zakat. Jenis dana yang dapat dihimpun oleh organisasi pengelola zakat tidak terbatas hanya zakat. Selain zakat, dana yang dapat dihimpun menurut Undang-Undang Nomor 38 Tahun 1999 tentang Pengelolaan Zakat adalah sebagai berikut zakat, infak, sedekah, wasiat, waris, kafarat, wakaf, hibah lembaga lain, hibah dari pemerintah, dan hibah dari luar negeri. Cara penerimaan dana masjid juga harus diperhatikan. Ada tiga cara dana diterima: melalui rekening di bank, langsung di masjid, dan "jemput bola", yaitu pengelola datang langsung kepada pemberi dana.

Kedua, penyaluran dana. Panduan dalam penyaluran dana setidaknya mencakup penerima dana, ruang lingkup bidang sasaran, sifat penyaluran, prosedur pengeluaran dana, dan pertanggungjawaban atas penggunaan dana. Dalam penyaluran dana ini ada beberapa hal yang perlu diperhatikan, yaitu: penerima/pengguna dana, ruang lingkup bidang sasaran, dan 
bentuk dan sifat penggunaan, apakah konsumtif ataukah produktif.

Ketiga, prosedur pengeluaran dana. Pengeluaran dana harus menggunakan prinsip kehati-hatian. Untuk itu, perlu adanya suatu panduan baku yang akan sangat membantu bagian keuangan sebagai pemegang dana dalam memenuhi atau menolak permintaan dana. Prosedur pengeluaran dana yang baku umumnya melibatkan pihak-pihak berikut: (a) pengguna dana, yaitu pihak yang mengajukan permintaan dana; (b) verifikator dan otorisator, yakni pihak yang berhak memverifikasi dan menyetujui pengeluaran dana; (c) kasir, yakni pihak yang bertindak sebagai juru bayar.

Keempat, pertanggungjawaban pengeluaran dana. Setiap pengeluaran dana harus ada pertanggungjawaban secara tertulis, lengkap, dan sah. Sekecil apapun dana yang dikeluarkan. Pertanggung jawaban harus dapat dinilai baik dari kesesuaian syariah maupun kebijakan lembaga. Pertanggung jawaban harus diberikan dalam batas waktu tertentu.

\section{Pengendalian/Pengawasan Keuangan}

Melakukan pengendalian dalam penghimpunan, penyaluran, dan saldo dana. Pengendalian keuangan ini meliputi unsur-unsur sebagai berikut, pertama, unit atau orang penanggung jawab keuangan. Dalam organisasi, baik besar atau kecil, harus ada unit atau orang tertentu yang menjadi penanggung jawab dalam pengelolaan keuangan. Tidak boleh terjadi setiap orang bertidak sebagai bendahara. Uang masuk dan keluar hanya dilakukan satu pintu. Kedua, anggaran. Anggaran merupakan alat pengendalian. Anggaran dapat dijadikan sebagai tolok ukur atau alat pembanding dalam mengevaluasi kegiatan. Ketiga, kebijakan. Kebijakan yang jelas dapat menghindarkan pengeluaran dan penggunaan dana oleh pihak-pihak yang tidak berkompeten. Keempat, pelaporan. Pelaporan dan publikasi merupakan sarana pengendalian keuangan yang melibatkan bukan hanya atasan melainkan seluruh masyarakat. Kelima, pencatatan. Dengan pencatatan maka setiap transaksi keuangan dapat ditelusuri. Keenam, prosedur. Setiap penerimaan atau pengeluaran harus melalui prosedur untuk menghindari penerimaan atau pengeluaran yang tidak sesuai. Ketujuh, audit internal. Audit internal dapat menghindarkan penyimpangan-penyimpangan karena kelalaian maupun kesengajaan baik terkait dengan syariah maupun etika umum yang berlaku di masyarakat. ${ }^{13}$

\section{Profil Yayasan Masjid Al- Maghfirah Surabaya}

Lokasi Masjid Al-Maghfirah terletak di Jalan Rungkut Asri Nomor 24 Surabaya. Bertempat di tanah fasilitas umum Perumahan YKP, Kelurahan Rungkut Kidul, Kecamatan Rungkut, Kota Surabaya. ${ }^{14}$ Berikut struktur dan jajaran kepengurusan Yayasan Masjid Al-Maghfirah Surabaya yakni:

\footnotetext{
${ }^{14}$ Dokumen Profil Masjid Al-Magfirah Surabaya
}

13 Hertanto Widodo \& Teten Kustiwana, Akutansi \& Manajemen Keuangan Pengelola Zakat, (Jakarta, Institut Manajemen Zakat, 2001), 76-91. 
Tabel 2 - Pengurus Masjid Al-Maghfirah Surabaya Tahun 2016

\begin{tabular}{r|l}
\hline Posisi Pengurus & Nama Pengurus \\
Ketua Dewan Pembina & H. Zainur Ketua \\
Dewan Pengawas & H. Wartikno \\
Dewan Pengurus (Takmir Masjid): & \\
Ketua Umum & H. Sudiro \\
Ketua 1 & H. Atim Mulyono. \\
Ketua 2 & Subur Sasongko SE. \\
Ketua 3 & H. Bachrum \\
Bendaha umum & Drs. H. M. Syamsu \\
Bendahara & H. Tarmidjan HW \\
Sekretaris umum & H. Gunarto. \\
Sekretaris & H. Rachmat Bhakti. \\
Departemen Peribadatan dan dakwah & H. Achmad Hadi \\
Departemen Sosial \& PHBI & H. Kus Hendarman. \\
Departemen Pendidikan Formal & H. Azis Budi Msi. \\
Departemen Pendidikan Nonformal & Hj. Eris Wartikno \\
Departemen Zakat Infak Sedekah & H. Azis Winanda \\
Departemen Pemberdayaan zakat & Ir. Adi Prawiro \\
Panitia Pembangunan & H. Daddy Adnan \\
\hline
\end{tabular}

\section{Analisis Perencanaan Keuangan Yayasan Masjid Al-Maghfirah}

Hasil observasi pada perencanaan keuangan Yayasan Masjid Al-Maghfirah Surabaya menunjukkan bahwa Pengurus masjid melakukan proses perencanaan anggaran penerimaan dan pengeluaran masjid untuk jangka waktu satu tahun. Proses pembentukan rencana anggaran penerimaan dan pengeluaran berawal dari masukan rencana kegiatan dari masingmasing departemen yang ditampung, lalu dilakukan analisis oleh Dewan Pengurus Masjid. Selanjutnya disampaikan kepada Dewan Pembina Masjid untuk dipertimbangkan dan diberi persetujuan. Hal ini ditunjukkan dari adanya dokumen RAPB (Rencana Anggaran Penerimaan dan Belanja) Yayasan Masjid Al-Maghfirah Surabaya Tahun 2016.
Untuk dapat mengetahui perencanaan yang dijalankan oleh Yayasan Masjid AlMaghfirah Surabaya, sumber data yang dapat digunakan adalah wawancara dari pengurus masjid sendiri. Dari hasil wawancara dengan Ketua Umum Dewan Pengurus Masjid pernyataan beliau mengenai perencanaan yakni: "Jadi gini kita kan di dalam misalkan sekarang anggaran tahun 2017 misalnya. Ini kan kita sudah meminta masukan dari masing-masing departemen, apa yang akan diusulkan dari departemen. Kita tampung, namun nanti kita evaluasi secara keseluruhan kenaikannya itu berapa persen. Kalau naiknya terlalu tinggi tidak mungkin juga, jadi wajar-wajar saja. Nanti pelaksanaan realisasi anggarannya sesuai itu yang kita rencanakan. Seperti sekarang ini kita sudah 
meminta dari masing-masing departemen melalui ketua yang bersangkutan kita tampung, kita evaluasi sebelum mendapatkan pengesahan dari Dewan Pembina. Disahkan dulu oleh dewan pembina, baru jadi RAPB (Rencana Anggaran Penerimaan dan Belanja) kita."15
Selain itu terdapat data dokumen Rencana Anggaran Penerimaan dan Belanja Tahunan yang dapat dijadikan bahan analisis untuk memahami perencanaan keuangan yang dilakukan oleh Yayasan Masjid Al-Maghfirah Surabaya, dokumen tersebut tertera di bawah ini:

Tabel 3 - Rencana Anggaran Penerimaan dan Belanja (RAPB) Tahun $2016^{16}$

\begin{tabular}{r|l|r|r|r}
\hline Kode & \multicolumn{1}{|c|}{ Bidang } & APB-2016 & \multicolumn{1}{|c}{$\begin{array}{c}\text { Realisasi Selama } \\
\text { 9 Bulan }\end{array}$} & $\begin{array}{c}\text { Prosentase } \\
\text { dari APB 2016 }\end{array}$ \\
\hline \hline & $\begin{array}{l}\text { BIDANG IMARAH } \\
\text { Sub Jumlah Bidang Imarah } \\
\text { BIDANG ZIS }\end{array}$ & 559.000 .000 & 468.489 .344 & $83,81 \%$ \\
& $\begin{array}{l}\text { Sub Jumlah Bidang ZIS } \\
\text { BIDANG TARBIYAH } \\
\text { Sub Jumlah Bidang Tarbiyah } \\
\text { SEKERTARIAT-YAMS18 } \\
\text { Sub Jumlah Sekertariat YAMS }\end{array}$ & 336.700 .000 & 284.728 .257 & $84,56 \%$ \\
\hline & \begin{tabular}{l} 
Jumlah Anggaran/Realisasi \\
\hline
\end{tabular}
\end{tabular}

Pada konteks Yayasan Masjid Al-Maghfirah Surabaya, sub variabel sumber dana yang terdapat di variabel perencanaan dapat diidentifikasi berdasarkan dokumen RAPB 2016 yang telah dibuat oleh Dewan Pengurus Masjid. Dari RAPB Masjid yang ada, dapat diketahui bahwa setiap departemen memiliki sumber dananya masing-masing untuk pelaksanaan program pada tiap-tiap departemennya. Jika dirincikan sumber dana yang dimiliki masing-masing departemen yakni:

Tabel 4 - Perincian Perencanaan Sumber Dana 2016

\begin{tabular}{|c|c|c|}
\hline No & Bidang & Sumber dana \\
\hline 1 & $\begin{array}{l}\text { Dep-Peribadatan dan } \\
\text { Dakwah }\end{array}$ & $\begin{array}{l}\text { Infak Jumat, infak tarawih, infak Idul Fitri, infak Idul Adha, infak } \\
\text { takjil, bagi hasil jasa giro rekening 1000, infak pengamal MTKI. }\end{array}$ \\
\hline 2 & Dep-Penghimpun ZIS & $\begin{array}{l}\text { Infak rutin, infak dan sedekah Ramadhan, zakat maal Ramadhan, } \\
\text { zakat maal profesi, zakat fitrah, fidiyah, penerimaan jasa giro } \\
\text { rekening } 3000 \text {. }\end{array}$ \\
\hline 3 & Dep-Pemberdayaan ZIS & Infak dan sedekah Lainnya, infak kurban. \\
\hline 4 & Dep-Pendidikan Formal & $\begin{array}{l}\text { Uang pangkal \& SPP PAUD, sumbangan PAUD, penerimaan jasa } \\
\text { giro rekening } 2000 .\end{array}$ \\
\hline 5 & Dep-Pendidikan Nonformal & $\begin{array}{l}\text { Infak tarbiyah Nurjanah, infak bulanan Nurjanah, infak syariah } \\
\text { tarbiyah dari wali santri. }\end{array}$ \\
\hline 6 & Sekertariat-YAMS & Penerimaan jasa giro rekening 4000 . \\
\hline
\end{tabular}

$15 \mathrm{H}$. Sudiro (Ketua Dewan Pengurus Yayasan Masjid Al-Magfirah Surabaya), Wawancara oleh Penulis, 13 November 2016, di Masjid Al-Magfirah, Surabaya.
16 Sumber: Dokumen Rencana Anggaran Penerimaan dan Belanja (RAPB) Masjid Al-Magfirah tahun 2016. ${ }^{17} \mathrm{APB}=$ Anggaran Penerimaan dan Belanja 18 YAMS = Yayasan Al-Magfirah Surabaya 
Dengan pembagian alur dan pemisahan dana yang masuk ke masjid, Hal ini membuat dana dari jemaah yang memiliki akad berbeda-beda tidak akan tercampur dalam proses penerimaannya. Dari sini menunjukan bahwa masing-masing departemen dalam kepengurusan masjid telah memiliki rencana masing-masing terkait dana yang akan terkumpul.

Pengumpulan dana yang sudah direncanakan, dalam tahap perencanaan terdapat variabel strategi pengumpulan dana. Strategi pengumpulan dana yang diterapkan oleh Yayasan Masjid AlMaghfirah Surabaya adalah dengan memperbanyak kotak amal pada momentum ibadah yang melibatkan banyak jemaah. Hal ini ditunjukan dari proses observasi langsung terdapat banyak kotak kaleng yang diletakkan di beberapa tempat antara lain: pada tiga pintu masuk ruang utama masjid, tempat penitipan barang, tempat berwudhu, depan pintu masuk ruang pengajian. Selain itu juga terdapat kotak amal khusus pembangunan masjid yang posisinya diletakkan di depan pintu ruang yang digunakan untuk pengajian. Begitu juga saat ibadah salat Jumat terdapat kotak amal besar yang diletakan didepan pintu utama masjid dan di pinggir setiap shaf/barisan yang nantinya berkeliling barisan pada saat khotbah Jumat berlangsung. Seperti pernyataan Ketua Umum Dewan Pengurus Masjid, "Kalau bulan ramadhan itu kira-kira 30 lebih 40 kotak, kalau Jumat paling-paling cuma 20 25 kotak yang jalan (keliling), disamping itu juga kita sediakan kotak-kotak yang disisisisi (sisi masjid). Lalu waktu kita lagi bangun

\footnotetext{
$19 \mathrm{H}$. Sudiro, wawancara.

$20 \mathrm{H}$. Rachmat Bhakti (Sekretaris Dewan Pengurus Yayasan Masjid Al-Magfirah Surabaya), Wawancara
}

kita juga sediakan kotak pembangunan besar." ${ }^{19}$

Selain itu metode jemput bola menjadi strategi lain yang dijalankan oleh pengurus Yayasan Masjid Al-Maghfirah Surabaya. Metode jemput bola ini merupakan strategi untuk mengumpulkan infak rutin dari Jemaah yang tinggal di area perumahan Rungkut YKP dan sekitarnya. Dalam teknisnya pengurus membentuk korwil (kordinator wilayah) yang bertugas untuk mengoordinasi dana infak jemaah dalam ruang lingkup 1 RW. Pada masing-masing korwil pun juga dibentuk subkorwil yang bertugas untuk mengkordinasi dalam ruang lingkup satu RT. Cara jemput bola yang dilakukan bervariasi menyesuaikan karakteristik masing-masing wilayah. Ada yang menggunakan ibu-ibu PKK, petugas keamanan ataupun kelompok Pengajian Wanita Nurjanah yang berada dalam struktur kepengurusan masjid dan jemaahnya berasal dari warga yang sama. Seperti pernyataan Sekretaris Masjid, "Diberi bukti kuitansi. Jadi nanti ketua korwil mengambil buktinya. Siapa-siapa korwil berapa, infak berapa. Ya itu tergantung sistem yang di pake masing-masing korwil itu seperti apa. Ada petugas satpam yang narikin, ada sistem pada waktu PKK, arisan ada. Tergantung sistem korwil masingmasing. Biasanya korwil membawahi RW, kalau sub korwil RT. Masing-masing sub korwil terserah bagaimana cara menariknya. Itu berdasarkan kesulitannya. Biasanya kalau PKKnya tidak jalan lewat satpam, kalau PKKnya jalan lewat PKK." 20

oleh Penulis, 14 November 2016, di Masjid AlMagfirah, Surabaya. 
Metode selanjutnya yang menjadi strategi Yayasan Masjid Al-Maghfirah Surabaya dalam mengumpulkan dana dari jemaah adalah melalui transfer rekening bank. Hal ini dibuktikan dari adanya nomor rekening masjid yakni A/C: 141-00-1096225-6 a/n: Yayasan Al Magfirah Surabaya yang disertakan pada backcover majalah AlMaghfirah yang disebarkan kepada para jemaah masjid. Dengan strategi-strategi yang variatif dalam pengumpulan dana diharapkan akan memudahkan pemberian dana dari Jemaah yang memiliki berbagai macam karakteristik pemberian.

Saat membahas perencanaan, selain ada anggaran penerimaan ada pula anggaran pengeluaran atau belanja. Dari hasil observasi yang dilakukan anggaran pengeluaran juga dimiliki oleh Yayasan Masjid Al-Maghfirah Surabaya yang tertuang dalam RAPB Masjid. Dalam perencanaan selain menyusun estimasi dana yang diterima juga menyusun estimasi dana yang keluar. Dalam RAPB 2016 Yayasan Masjid Al-Maghfirah Surabaya ditemukan estimasi dari setiap dana yang dikeluarkan. Setiap pengeluaran yang ada akan diakumulasi untuk mengetahui keseluruhan pengeluaran masjid. Total jumlah dana yang dikeluarkan oleh masjid Al-Maghfirah Surabaya pada tahun 2016 yakni sebesar Rp 1.381.200.000 dalam satu tahun. Hal ini selain menjadi pedoman juga akan menjadi kontrol dalam melakukan pengeluaran dana. Semua rencana pengeluaran dicantumkan dalam RAPB Masjid seperti berikut.

Tabel 5 - Rencana Anggaran Pengeluaran Tahun $2016^{21}$

\begin{tabular}{r|l|r|r|r}
\hline Kode & \multicolumn{1}{|c|}{ Bidang } & \multicolumn{1}{c|}{ APB-2016 } & \multicolumn{1}{c|}{$\begin{array}{c}\text { Realisasi } \\
\text { Selama 9 Bulan }\end{array}$} & \multicolumn{1}{c}{$\begin{array}{c}\text { Prosentase dari } \\
\text { APB 2016 }\end{array}$} \\
\hline \hline & $\begin{array}{l}\text { BIDANG IMARAH } \\
\text { Sub Jumlah Bidang Imarah }\end{array}$ & 559.000 .000 & 73.386 .320 & $13,13 \%$ \\
& $\begin{array}{l}\text { BIDANG ZIS } \\
\text { Sub Jumlah Bidang ZIS }\end{array}$ & 336.700 .000 & 355.595 .430 & $105,61 \%$ \\
& $\begin{array}{l}\text { BIDANG TARBIYAH } \\
\text { Sub Jumlah Bidang Tarbiyah }\end{array}$ & 484.700 .000 & 121.916 .054 & $25,15 \%$ \\
& $\begin{array}{l}\text { SEKERTARIAT-YAMS } \\
\text { Sub Jumlah Sekertariat YAMS }\end{array}$ & 800.000 & 760.265 .768 & $95033.22 \%$ \\
\hline & Jumlah Anggaran/Realisasi & $\mathbf{1 . 3 8 1 . 2 0 0 . 0 0 0}$ & $\mathbf{1 . 3 1 1 . 1 6 3 . 5 7 2}$ & $\mathbf{9 4 . 9 3 \%}$ \\
\hline
\end{tabular}

Dalam perencanaan pengeluaran terdapat variabel jumlah orang atau pihak yang menerima. Hal ini dapat dimaknai apa saja pos-pos yang menjadi pengeluaran pada masjid Al-Maghfirah Surabaya. Dari RAPB
Masjid yang ada dapat diketahui bahwa setiap departemen memiliki pos penyaluran dananya masing-masing. Pos penyaluran dana dari masing-masing departemen antara lain yakni:

21 Smuber: Dokumen RAPB Masjid Al-Magfirah Tahun 2016. 
Tabel 6 - Perencanaan Penyaluran Dana

\begin{tabular}{|c|c|c|}
\hline No & Bidang & Penyaluran Dana \\
\hline 1 & $\begin{array}{l}\text { Dep-Peribadatan } \\
\text { Dakwah }\end{array}$ & $\begin{array}{l}\text { Honor petugas masjid, honor petugas administrasi, salat Jumat, } \\
\text { biaya administrasi rekening } 1000 \text {, dakwah, (ibadah Ramadhan, } \\
\text { Idul Fitri dan Idul Adha), panitia buka bersama, aktiva tetap. }\end{array}$ \\
\hline 2 & Dep PHBI dan Sosial & $\begin{array}{l}\text { Penyelenggaraan } \mathrm{PHBI} \text {, penerimaan jemaah haji/hajjah baru, } \\
\text { sosial kematian, panitia khitan bersama. }\end{array}$ \\
\hline 3 & Sekertariat-Imarah & $\begin{array}{l}\text { Sekertariat peribadatan, rekening PDAM dan } \\
\text { pemelihara/kebersihan, rekening PLN dan pemeliharaan instalasi, } \\
\text { surplus/subsidi YAMS-bidang imarah. }\end{array}$ \\
\hline 4 & Dep-Penghi & Hak fidiyah, biaya operasional. \\
\hline 5 & an ZIS & $\begin{array}{l}\text { Program infak rutin, hak zakat fitrah, hak fakir miskin, hak } \\
\text { sabilillah, panitia kurban, biaya operasional. }\end{array}$ \\
\hline 6 & Sekertariat-ZIS & $\begin{array}{l}\text { Biaya administrasi bank rekening 3000, surplus/(subsidi) YAMS- } \\
\text { bidang ZIS. }\end{array}$ \\
\hline 7 & Dep-Pendidika & Sarana PAUD, biaya operasional PAUD, pinjaman pendirian PAUD. \\
\hline 8 & Dep-Pendidikan Non Formal & $\begin{array}{l}\text { Biaya operasional PW Nurjanah, biaya operasioanl TPQ Al- } \\
\text { Maghfirah, program remaja masjid. }\end{array}$ \\
\hline 9 & Sekertariat-Tarbiyah & $\begin{array}{l}\text { Sekertariat (pengamal/pendidikan), biaya administrasi bank } \\
\text { rekening 2000, surplus/subsidi YAMS bidang tarbiyah. }\end{array}$ \\
\hline 10 & Sekertariat-YAMS & $\begin{array}{l}\text { Bangunan dan pembangunan, sekertariat yayasan, cadangan } \\
\text { biaya tak terduga YAMS, biaya administrasi bank rekenin } 4000 \text {, } \\
\text { surplus/subsidi YAMS-sekertariat. }\end{array}$ \\
\hline
\end{tabular}

Setiap penyaluran dana yang berada di bidangnya masing-masing merupakan masukan-masukan dari anggota departemen terkait melalui ketua departemennya. Selanjutnya dilakukan evaluasi bersama untuk memutuskan persetujuan dalam pengeluaran dana. Sehingga hal ini menunjukan bahwa pengelolaan Masjid Al-Maghfirah juga menerapkan buttom up system, yang itu memberikan ruang yang lebih luas pada anggota untuk berpendapat, dengan cara ikut serta dalam merumuskan dan mengevaluasi perencanaan dana yang telah dibuat.

Lalu untuk adanya kondisi pengeluaran tak terduga dan diluar perencanaan harus ada upaya untuk melakukan antisipasi. Dalam hal ini bentuk antisipasi adalah adanya saldo minimum. Saldo minimum berfungsi ketika sewaktu-waktu ada pengeluaran yang tidak terduga. Dalam hal saldo cadangan Yayasan Masjid Al-Maghfirah Surabaya memiliki dua cara untuk mengatasi pengeluaran yang tidak terduga. Pertama, dari hasil observasi ditemukan bahwa dalam RAPB Masjid terdapat adanya pos cadangan biaya tak terduga YAMS yang ini direncanakan senilai Rp 10.000.000. Kedua, pengurus Yayasan Masjid Al-Maghfirah Surabaya juga menerapkan sistem subsidi silang antar rekening yang dimiliki masjid, terkecuali pada rekening 3000 (rekening zakat) yang itu sudah baku dalam penyalurannya. Hal ini selaras dengan pernyataan Ketua Umum Dewan Pengurus Masjid antara lain yakni: "Ini kalau pengaturan subsidi, kalau yang itu kecuali zakat. Kalau zakat sudah tidak bisa. Kalau zakat kan memang zakat jadi alokasinya harus zakat. Tapi kalau yang lainlain kan fleksibel. Cuma biasanya ketika 
nyusun anggaran sudah direncanakan jadi jarang terjadi." ${ }^{\prime 22}$

Sehingga dengan adanya back up dalam hal dana. Hal ini dapat menjadi jaminan bagi pengurus untuk dapat terus menjalankan kegiatan dakwah dan sosial yang ada di Masjid Al-Maghfirah.

\section{Analisis Pengelolaan Dana Yayasan Masjid Al-Maghfirah Surabaya}

Dalam pengelolaan keuangan terdapat aktivitas penerimaan dan penyaluran keuangan. Adanya pengaturan dalam pengelolaan keuangan, hal ini sebagai bentuk antisipasi untuk meminimalisir terjadinya kesalahan dalam penyaluran. Berdasarkan hasil penelitian pengaturan pengelolaan yang dilakukan Yayasan Masjid Al-Magfrah Surabaya antara lain:

\section{Analisis Penghimpunan Dana}

Pada sub variabel penghimpunan dana memiliki dua aspek, yaitu jenis dana yang di himpun dan cara dana tersebut di terima. Dalam hal jenis dana yang dihimpun Yayasan Masjid Al-Maghfirah Surabaya membaginya menjadi empat jenis yang nantinya dibedakan berdasarkan rekening bank yang dibuat untuk menampung dana. Hal ini seperti yang disampaikan oleh Sekertaris Masjid, "Kalau (rekening) 1000 dari peribadatan biasanya dari infak Jumat, infak tarawih. Yang 2000 itu dari infak rutin yang kematian. Yang 3000 itu dari zakat. Yang 4000 itu pembangunan." 23

\footnotetext{
$22 \mathrm{H}$. Sudiro, Wawancara oleh Penulis, 15 Desember 2016, di Masjid Al-Magfirah, Surabaya.

${ }^{23}$ H. Rachmat Bhakti, Wawancara oleh Penulis, 17 Oktober 2016, di Masjid Al-Magfirah, Surabaya.
}

Pada rekening yang pertama yaitu rekening 1000. Jenis dana yang dihimpun adalah dana-dana infak yang secara sifat berasal dari infak para Jemaah yang datang dan melakukan ibadah di masjid seperti, infak salat Jumat, salat hari raya, salat Tarawih. Secara niat pemberian bersifat umum. Sehingga penggunaan dana bersifat fleksible dalam memenuhi kebutuhan masjid. Pada rekening yang kedua yaitu rekening 2000 . Jenis dana yang dihimpun adalah dana infak yang berasal dari infak rutin (setiap bulan) dari para jemaah yang tinggal di wilayah 7 RW yakni YKP Rungkut Lor RW XI, X, IX dan YKP Rungkut Kidul RW XII, VI, VII, $\mathrm{XI}^{24}$ yang berada di sekitar masjid dan secara tujuan untuk mendanai program sosial kematian bagi warga yang tinggal di 7 RW tersebut dan untuk pengembangan pendidikan di masjid. Secara niat pemberian bersifat khusus, sehingga dana ini diprioritaskan untuk penggunaan program sosial kematian dan pendidikan.

Pada rekening yang ketiga yaitu rekening 3000. Jenis dana yang dihimpun pada rekening ini adalah dana-dana zakat yang berupa zakat maal, zakat profesi, dan juga infak serta sedekah. Secara pemberian niat sudah khusus dan tujuan pemberian sudah spesifik pada delapan golongan penerima zakat. Dana ini tidak dapat digunakan untuk memenuhi kebutuhan yang selainnya. Hal ini didasarkan pada syariat Islam yang berpijak pada Alquran surah Attaubah ayat 60 yaitu: "Sesungguhnya zakat itu hanyalah untuk orang-orang fakir, orang miskin, amil zakat, yang dilunakan hatinya (mualaf), untuk (memerdekakan) hamba sahaya, untuk (membebaskan) orang yang berhutang, untuk jalan Allah dan untuk orang yang sedang dalam perjalanan,

\footnotetext{
${ }^{24}$ Buku Khutbah Idul Fitri 1437 H Masjid Al-Magfirah Surabaya.
} 
sebagai kewajiban dari Allah. Allah Maha mengetahui, Maha bijaksana." 25

Pada rekening yang keempat yaitu rekening 4000. Jenis dana yang dihimpun di rekening ini adalah dana-dana infak dari para jemaah yang diniatkan untuk program pembangunan dan pengembangan masjid. Maka secara karakteristik dana khusus dialokasikan dan diprioritaskan untuk kegiatan pembangunan Masjid AlMaghfirah yang dilaksanakan dalam beberapa tahapan.

Untuk metode penerimaan yang diterapkan dalam menghimpun seluruh jenis dana. Masjid Al-Maghfirah Surabaya menerapkan tiga metode yaitu melalui rekening di bank, langsung di masjid, dan "jemput bola." Pertama, rekening bank. Masjid Al-Magfiah Surabaya memiliki rekening bank. Informasi rekening dicantumkan dalam majalah AlMaghfirah yang dibagikan rutin kepada para jemaah. Informasi yang disertakan berupa anjuran untuk infak pembangunan bisa melalui transfer ke Bank Mandiri A/C: 14100-1096225-6 a/n: Yayasan Al Magfirah Surabaya. Jenis sumber dana yang terkumpul dari strategi rekening bank adalah infak pembangunan masjid.

Kedua, langsung di masjid. Masjid AlMaghfirah Surabaya menyediakan kotak kaleng yang diletakan di masjid sehingga jemaah dapat memasukan kedalam kotak kaleng tersebut. Kotak kaleng akan dikeluarkan lebih banyak lagi saat jemaah yang hadir bertambah banyak pada moment tertentu seperti salat Jumat, Salat Hari Raya Idul Fitri dan seterusnya. Untuk pemberian infak langsung yang diniatkan untuk pembangunan masjid terdapat kotak amal sendiri yang berukuran lebih besar dan diletakan di depan pintu utama ketika

25 Departemen Agama Republik Indonesia, Al-Qur'an dan Terjemah (Jawa Barat, Cipta Bagus Segara, 2014), 196. menghadirkan jemaah yang banyak seperti salat Jumat. Jenis sumber dana yang terkumpul melalui strategi langsung di masjid adalah sumber dana yang didapat dari kaleng kotak antara lain seperti infak Jumat, infak tarawi, infak Idul Fitri, infak Idul Adha, dan seterusnya. Ketiga, jemput bola. Masjid Al-Maghfirah Surabaya membentuk kepengurusan yang bertugas untuk datang langsung kepada jemaah pemberi dana "jemput bola." Dalam Masjid Al-Maghfirah ada DIR (Dana Infak Rutin) yang ini senantiasa di tawarkan setiap bulan kepada jemaah yang tinggal di area tujuh RW yang ada di sekitar masjid dan berinfak rutin ke masjid Al-Maghfirah. Pengurus Masjid AlMaghfirah membentuk delapan korwil yang setiap korwilnya membawahi 1 RW (kecuali Wilayah YKP RK 2 - RW VI Rungkut Kidul karena jumlah RT-nya yang banyak maka di backup oleh dua korwil) dan masing-masing korwil membawahi beberapa sub korwil. Setiap sub korwil membawahi satu RT. Selain itu sub korwil lah yang mengingatkan dan menawarkan infak rutin kepada para Jemaah. Jenis sumber dana yang terkumpul dari strategi jemput bola adalah infak rutin.

\section{Analisis Penyaluran Dana}

Sebagai sumber data aktivitas penyaluran dana didapat dari hasil observasi langsung dengan mengikuti kegiatan Majelis Taklim Kajian Islam (MTKI) dan ibadah salat Jumat, juga berdasarkan dokumen. Pada Yayasan Masjid Al-Maghfirah Surabaya menjalankan berbagai kegiatan dakwah dan keagamaan yaitu: ibadah salat Jumat, pengajian bapakbapak yang dilaksanakan pada malam hari di hari Rabu dan Jumat, pengajian malam Majelis Taklim Kajian Islam (MTKI) pada hari kamis, pengajian ibu-ibu yang dilaksanakan pada sore hari, kegiatan pendidikan PAUD- 
TK yang dilaksanakan pada sore hari. Juga peminjaman dana untuk usaha pada jemaah. Terkait peminjaman dana untuk usaha seperti pernyataan Ketua Umum Dewan Pengurus Masjid yakni: "Kita kan dasarnya dari masukan para jemaah terutama ibu-ibu. Itu banyak dari jemaah kita tetangganya atau mungkin dari jemaah kita yang pinjam uang dari uang rentenir. Dari pengalaman itu, kita kan ada dana yang mau kita perbantukan, tapi giliran. misalkan sekarang mampunya memberi sebanyak 10 orang ibu-ibu, mungkin bulan berikut kita bisa memberikan ke 15 ibu yang dipinjamkan". ${ }^{26}$

Secara garis besar dan umum, kegiatankegiatan telah tercantum dalam jadwal kegiatan masjid. Berdasarkan data yang ditemukan dan dianalisis secara induksi. Menjelaskan bahwa dana yang terkumpul di Yayasan Masjid Al-Maghfirah dikelola untuk menjalankan kegiatan yakni: (a) pelaksanaan kegiatan ibadah mulai dari ibadah salat lima waktu, ibadah Jumat, ibadah salat tarawih, ibadah salat Idul Fitri, ibadah salat Idul Adha; (b) pelaksanaan kegiatan dakwah seperti kegiatan pengajian bapak-bapak sehabis magrib di hari rabu dan Jumat, pengajian MTKI, pengajian ibu-ibu setiap sore, pelaksanaan PHBI seperti peringatan tahun baru Muharam; (c) pelaksanaan kegiatan tarbiyah (pendidikan) seperti pelaksanaan pendidikan PAUD-TK; (d) pelaksanaan kegiatan sosial keagamaan seperti, pengalokasian ZIS kepada mustahik (8 golongan), pelaksanaan Idul Qurban, pelaksanaan sosial kematian, pelaksanaan takjil; (e) pelaksanaan kegiatan ekonomi pemberian pinjaman dana untuk usaha kepada jemaah; (f) pelaksanaan perawatan dan pengembangan masjid seperti pemeliharaan dan pembangunan masjid.
Dari berbagai macam kegiatan yang diselenggarakan di Masjid Al-Maghfirah menunjukkan bahwa penerima/pengguna dana masjid, antara lain adalah orang-orang yang melaksanakan program dan merasakan manfaat-manfaat dari program yang dijalankan masjid. Mereka adalah jemaah Masjid Al-Maghfirah yang tinggal di tujuh RW sekitar masjid, para mustahik (delapan golongan penerima zakat), para santri yang belajar di tarbiyah masjid, jemaah masjid yang berasal dari luar lingkungan masjid, para pengurus dan karyawan masjid.

Dalam hal sifat penyaluran dana secara jenis terbagi menjadi dua yakni penyaluran dana yang langsung dikonsumsi/digunakan oleh pengguna dana dan penyaluran dana yang itu untuk produksi atau adanya orientasi kemandirian/peningkatan ekonomi dari pengguna dana. Lalu pada Yayasan Masjid Al-Maghfirah Surabaya terdapat penyaluran dana bersifat langsung dikonsumsi/digunakan seperti halnya kegiatan pelaksanaan Idul Adha, pembagian takjil, pelaksanaan sosial kematian dan sebagainya. Selain itu Yayasan Masjid Al-Maghfirah Surabaya juga melakukan penyaluran yang bersifat peningkatan ekonomi dari pengguna dana, yakni dalam program pemberian pinjaman dana kepada para jemaah ataupun tetangga yang sedang mengalami kesulitan dalam menjalankan kegiatan ekonomi.

\section{Analisis Prosedur Pengeluaran}

Dalam prosedur pengeluaran dana setidaknya melibatkan tiga pihak yaitu: (a) pengguna, (b) verifikator dan otorisator, dan (c) kasir. Dalam hal prosedur pengeluaran dana, pengguna dana adalah departemen

26 H. SudiroMinggu, Wawancara oleh Penulis, 13 November 2016, di Masjid Al-Magfirah, Surabaya. 
dan kepanitiaan yang dibentuk oleh pengurus dan memiliki program-program yang harus dijalankan. Mekanismenya adalah masing-masing departemen melakukan pengajuan yang diwakili oleh ketua departemen. Setelah mendapat persetujuan baru departemen terkait dapat meminta pencairan dana kepada bendahara. Yang terlibat menjadi verifikator adalah pengurus takmir pada rekening 1000 , pengurus DIR pada rekening 2000, pengurus DAZ pada rekening 3000 dan ketua umum/I/II pada rekening 4000. Hal ini dikarenakan untuk pengeluaran dana pada setiap departemen harus dengan sepengetahuan dari pengurus departemen terkait. Setiap pengeluaran dana yang dilakukan pada masing-masing departemen harus sudah memiliki persetujuan dari Ketua umum dewan pengurus masjid. Hal ini menunjukan bahwa ketua umum dewan pengurus masjid menjadi otorisator, karena berhak untuk memutuskan pengeluaran dana mana saja yang boleh dan tidak boleh dilakukan. Kasir, dalam Yayasan Masjid AlMaghfirah Surabaya adalah bendahara Yayasan Al-Maghfirah Surabaya (YAMS) yang mencairkan dana dari bank sekaligus menyerahkan dana kepada pihak yang mengajukan. Sehingga dari sini menunjukan bahwa dalam pelaksanaannya, prosedur pengeluaran dana Yayasan Masjid AlMaghfirah Surabaya melibatkan beberapa pihak dan yang menjadi pengguna dana, verifikator dan otorisator juga kasir adalah orang yang berbeda. Hal ini untuk mengantisipasi adanya penyalahgunaan pengeluaran yang tidak semestinya. Sehingga dari situ menunjukan secara prosedur pengeluaran yang diterapkan oleh

27 Dokumen SOP Keuangan Yayasan Masjid AlMagfirah Surabaya.
Yayasan Masjid Al-Maghfirah Surabaya sudah baik dan mapan.

\section{Analisis Pertanggung Jawaban Pengeluaran}

Dalam pertanggung jawaban pengeluaran dana, prinsipnya adalah harus ada pertanggung jawaban secara tertulis, lengkap dan sah. Sehingga dapat dibuktikan sewaktu-waktu ketika dibutuhkan. Pada Yayasan Masjid Al-Magifah Surabaya terkait aktifitas pertanggungjawaban pengeluaran memiliki ketentuan untuk senantiasa mengisi form C-1 yang merupakan bukti kas keluar, ketika hendak melakukan pembelanjaan. Lalu setelah itu nantinya anggota yang melakukan perbelanjaan melaporkan pada bendahara beserta bukti eksternal yang didapat dari belanja tersebut berupa struk atau nota belanja. Bukti eksternal tersebut nanti akan menjadi lampiran dari setiap C-1 yang dicatat sesuai dengan keterangannya. Lalu dokumen tersebut disimpan oleh bendahara. Ketentuan ini tertuang dalam dokumen SOP (Standar Operasional Prosedur) Pengelolaan Keuangan Yayasan Masjid Al-Maghfirah Surabaya yang bertuliskan: "Seluruh transaksi pengeluaran KAS YAMS harus menggunakan form C-1. Diisi dan dikerjakan oleh masing-masing bendahara. Lampirkan dokumen (nota) untuk pembelian perlengkapan-inventaris-barang lainnya. ${ }^{27}$

Dengan adanya ketentuan tersebut membuat setiap pengeluaran yang dilakukan pengurus masjid selalu ada rekam jejak dan bukti fisiknya. Sehingga dapat menjadi alat pertanggung jawaban yang sah dalam melakukan pembelanjaan dana masjid. 


\section{Analisis Pengendalian Yayasan Masjid Al-Maghfirah Surabaya}

Kegiatan pengendalian dijalankan bertujuan untuk mengontrol jalannya pengelolaan keuangan, agar tidak terjadinya penyimpangan pada proses penghimpunan ataupun pengeluaran dana. Untuk dapat mengetahui bentuk pengendalian yang dijalankan oleh Yayasan Masjid AlMaghfirah Surabaya dilihat dari beberapa aspek yakni: (1) unit atau orang penanggung jawab keuangan; (2) anggaran; kebijakan; (4) pelaporan; (5) pencatatan; (6) prosedur; dan (7) audit internal.

Pada pelaksanaan pengendalian keuangan Yayasan Masjid Al-Maghfirah Surabaya, data yang digunakan untuk menganalisis sub variabel pengendalian berpijak pada data wawancara dengan pengurus dan dokumen keuangan yang ada. Dari hal tersebut dapat tergambar antara lain:

\section{Unit atau Orang Penanggung Jawab Keuangan}

Dalam hal unit atau orang penanggung jawab keuangan Dewan Pengurus Masjid AlMaghfirah membentuk unit yang mengemban tugas untuk bertanggung jawab dalam hal pengelolaan keuangan Masjid Al-Maghfirah, yakni pada unit bendahara. Pada unit bendahara terbagi menjadi bendahara umum yang dijabat oleh bapak Drs. H. M. Syamsu, dan pada bendahara yang dijabat oleh bapak $\mathrm{H}$. Tarmidjan H.W. dengan tugas mengatur keuangan harian. Hal ini dapat dilihat dari Struktur Organisasi Dewan Pengurus Masjid Al-Maghfirah Surabaya. Untuk pemilihan pengurus yang ditempatkan pada unit atau orang penanggung jawab keuangan, pengurus Yayasan Masjid Al-Maghfirah mengutamakan aspek kepribadian yang jujur dan juga memiliki kompetensi untuk menjalankan tugas bendahara. Hal ini agar menghindari adanya penyalahgunaan dana dan juga meminimalisir adanya kesalahan yang diperbuat. Seperti yang dijelaskan oleh Sekertaris Masjid yakni: "Prinsip utamanya yang (dapat) dipercaya, makanya meskipun dia kurang kuat dalam basic keuangan, tapi dipercaya tidak masalah."28

Dengan adanya unit atau orang tersendiri yang mengelola dana, maka arus keuangan mulai dari pemasukan dan pengeluaran masjid akan dapat terkelola dan tercatat dengan baik, dikarenakan sudah ada unit yang dibentuk untuk memfokusi hal tersebut.

\section{Anggaran}

Untuk dapat menghindari munculnya persoalan pengeluaran yang seharusnya tidak dilakukan ataupun nominal pengeluaran yang dianggap berlebihan. Perlu adanya tolak ukur/pijakan yang jelas dalam melakukan pengeluaran dana. Bentuk pengendalian keuangan berbasis anggaran menjadi salah satu tolak ukur yang jelas. Pada pengelolaan dana Yayasan Masjid AlMaghfirah Surabaya setiap pengeluaran dana yang hendak dilakukan untuk keperluan masjid dan jemaah selalu melalui proses penganggaran terlebih dahulu. Tidak bisa serta-merta langsung meminta dana dan dapat langsung menggunakannya. Proses penganggaran dilakukan dengan cara mengajukan proposal program dari masingmasing departemen. Proposal program

28 H. Rachmat Bhakti, Wawncara oleh Penulisa, 10 Oktober 2016, di Masjid Al-Magfirah Surabaya. 
disertakan dengan kebutuhan-kebutuhan yang harus dipenuhi sehingga dari situ muncul rincian kebutuhan dana yang diperlukan untuk dapat menjalankan program. Rincian dari estimasi pengeluaran terlebih dahulu harus di ketahui oleh ketua. $\mathrm{Hal}$ ini didukung dengan penjelasan dari Ketua Umum Dewan Pengurus Masjid, "Disini tidak pernah kita tanpa rencana, pake rencana pasti. Kan kita tahunya kegiatan dari departemen. Setiap tahun sebelumnya tahun 2017. Kita menganggarkan dari masing-masing departemen. Di tiap departemen itu punya kegiatan apa saja. Nah kegiatan ini kita usahakan penyusunannya sesuai prioritas keperluan. Jadi nanti dari kegiatan itu akan muncul anggaran. Tanpa kegiatan anggaran tidak akan bisa muncul, dan nanti kita waktu mengevaluasi dari sini aja. Disini semua pake anggaran, pake rencana. ${ }^{129}$

Di sisi lain penganggaran juga menjadi instrumen evaluasi pengurus masjid dalam pengeluaran dana dan realisasi program. Hal ini ditunjukan dari adanya pengukuran presentase pelaksanaan penghimpunan dan pengeluaran dana berdasarkan perencanaan seperti yang tercantum pada data RAPB 2016. Disitu ada prosentase pelaksanaan dana dalam kurun waktu sembilan bulan yang telah berlangsung. Sehingga anggaran pada Masjid Al-Maghfirah juga memiliki kedudukan sebagai alat dalam mengendalikan keuangan masjid.

\section{Kebijakan}

Kejelasan kebijakan yang dibuat dapat terindikasi dari seberapa jauh dan detail rule yang dibuat untuk mengatur setiap perilaku dalam proses pengelolaan keuangan. Dalam

${ }^{29} \mathrm{H}$. Sudiro, Wawancara oleh Penulis, 13 November 2016, di Masjid Al-Magfirah, Surabaya. praktiknya pada Yayasan Masjid AlMaghfirah Surabaya, pengelolaan keuangan masjid memiliki kebijakan/ketentuan umum berupa surat keputusan dan kebijakan/ketentuan teknis berupa SOP Keuangan Pengurus Masjid Al-Maghfirah. Hal ini ditunjukkan dari adanya SK Pembina Yayasan Al-Maghfirah Surabaya Nomor 002 tahun 2009 tentang Standar Operasional Prosedur Keuangan Yayasan Al-Maghfirah Surabaya sebagai ketentuan dasar dalam melakukan pengelolaan keuangan, dan prosedur pelaksanaan keuangan.Kebijakan tersebut menjadi pedoman bagi para pengurus masjid untuk berperilaku dalam pengelolaan keuangan masjid. Sehingga kebijakan keuangan yang dimiliki oleh Yayasan Masjid Al-Maghfirah Surabaya dapat dinilai cukup jelas mengingat kebijakan yang ditetapkan sudah sampai ranah teknisnya dan dapat dijadikan sebagai instrumen dalam mengendalikan pengelolaan keuangan masjid.

\section{Pelaporan}

Pelaporan menjadi bentuk penginformasian dan pertanggungjawaban dari pihak yang menjalani aktivitas keuangan kepada pihak yang berwenang dalam mengetahui bagaimana berjalannya keuangan. Dalam hal pelaporan keuangan pada Yayasan Masjid Al-Maghfirah Surabaya memiliki ketentuan yang berlaku yakni pelaporan dilakukan secara berkala selama setahun yakni setiap triwulan (tiga bulan sekali) dengan laporan keuangan yang dibuat beberapa copy untuk nantinya diberikan kepada pihak pembina, pihak pengawas dan pihak pengurus untuk diperiksa. Lalu laporan keuangan tersebut juga di lampirkan dalam Majalah Al-Maghfirah yang 
terbit berkala dan dibagikan kepada seluruh jemaah yang ikut dalam infak rutin. Sehingga dalam pelaksanaan pelaporan keuangannya, Yayasan Masjid Al-Maghfirah melibatkan ketiga dewan tertinggi dalam struktur yakni Dewan Pembina Masjid, Dewan Pengurus Masjid dan Dewan Pengawas Masjid, serta melibatkan jemaah sebagai pihak eksternal. Hal ini didukung oleh pernyataan Ketua Umum Dewan Pengurus Masjid, "Laporan itu kita buat triwulanan dan di situ dilaporan itu kita sekaligus mengevaluasi diri kita. Laporan ke pengurus, pengawas, pembina. Laporan keuangan yang kita masukin dalam bulletin itu masalah pembangunan. ${ }^{\prime 30}$

Juga pada SK Pembina Yayasan Al-Maghfirah Surabya Nomor 002 tahun 2009 tentang Standar Operasional Prosedur Keuangan Yayasan Al-Maghfirah Surabaya yakni: "Laporan Keuangan YAMS dibuat 4 kali dalam setahun yaitu Triwulan 1, Semester 1, Triwulan 3 dan Akhir Tahun. Khusus untuk Keuangan Sosial Kematian, PW Nur Jannah dan TPQ Al Maghfirah Laporan Keuangan dibuat setiap Bulan disampaikan kepada Ketua Umum melalui Sekretaris Umum YAMS. ${ }^{\prime \prime 1}$ Sehingga dari sini dapat dipahami bahwa pelaporan keuangan Yayasan Masjid Al-Maghfirah Surabaya dilakukan tidak hanya kepada atasan namun juga kepada masyarakat.

\section{Pencatatan}

Pencatatan menjadi hal yang penting sebagai alat pengecekan dari berbagai aktivitas transaksi yang telah berlangsung. Pada pengelolaan keuangan Yayasan Masjid Al-Maghfirah Surabaya, pencatatan yang jalankan adalah seluruh aktivitas transaksi

$30 \mathrm{H}$. Sudiro, Wawancara oleh Penulis, 3 November 2016, di Masjid Al-Magfirah, Surabaya. yang terdapat pada masjid. Baik yang itu bersifat uang ataupun barang mulai dari proses penerimaan ataupun proses pengeluaran keuangan. Hal ini tertuang dalam SK Pembina Yayasan Al-Maghfirah Surabya Nomor 002 tahun 2009 tentang Standar Operasional Prosedur Keuangan Yayasan Al Magfirah Surabaya, "Seluruh penerimaan ZIS harus disetor langsung ke Bank sesuai sumber penerimaan, seluruh transaksi Bank Masuk dicatat di masingmasing Buku Bank. Pengeluaran untuk penyaluran ZIS harus melalui Bank dengan cara mengambil tunai dengan cek atau bilyet giro (apabila ada pembayaran langsung ke pihak ketiga), seluruh transaksi Bank Keluar dicatat di Buku Bank di masingmasing rekening. Seluruh pencatatan transaksi keuangan Yayasan dilaksanakan oleh Petugas Administrasi Yayasan dengan ketentuan Format dan Formulir yang telah ditetapkan. Seluruh Dokumen Keuangan Yayasan disimpan oleh Bendahara YAMS." ${ }^{\prime 32}$ Sehingga dengan begitu pencatatan yang dilakukan oleh pengurus masjid mulai dari penerimaan dan pengeluaran dana memiliki pengaturan yang ketat dan rekam jejak yang jelas. Hal ini akan memudahkan dalam kegiatan penelurusan keuangan sebagai bentuk kontrol.

\section{Prosedur}

Dalam hal prosedur penerimaan dan pengeluaran keuangan yang dijalankan pada Yayasan Masjid Al-Maghfirah Surabaya. Hal ini dijelaskan secara umum dalam SK Pembina Yayasan Al-Maghfirah Surabaya Nomor 002 tahun 2009 tentang Standar Operasional Prosedur Keuangan Yayasan Al Magfirah Surabaya: (a) Penerimaan ZIS:

\footnotetext{
${ }^{31}$ Dokumen Surat Keputusan Pembina Yayasan AlMagfirah Surabaya Nomor 002 Tahun 2009. 32 Ibid.
} 
Seluruh penerimaan ZIS harus disetor langsung ke bank sesuai sumber penerimaan, seluruh transaksi Bank Masuk dicatat di masing-masing Buku Bank yaitu di Rekening 1000, 2000 dan 3000; (b) Penyaluran ZIS: Pengeluaran untuk penyaluran ZIS harus melalui Bank dengan cara mengambil Tunai dengan Cek atau Bilyet Giro (apabila ada pembayaran langsung ke pihak ketiga), seluruh transaksi Bank Keluar dicatat di Buku Bank di masingmasing Rekening 1000, 2000 dan 3000; (c) Tanda tangan cek/bilyet giro: Yang berhak menandatangani Cek atau Bilyet Giro harus 2 (dua) orang yaitu Ketua Umum dan Bendahara Umum. Apabila Ketua Umum berhalangan diwakilkan kepada salah satu Ketua dan apabila Bendahara Umum berhalangan diwakilkan kepada Bendahara YAMS." ${ }^{\prime 3}$

Dari sini dapat diketahui bahwa dalam melakukan penerimaan dan pengeluaran dana pada masjid tidak dilakukan dengan bebas, melainkan ada tata cara yang telah ditentukan dalam bentuk SOP. Dengan begitu adanya ketentuan/prosedur dalam bentuk SOP yang dimiliki oleh masjid.

\section{Audit Internal}

Untuk meminimalisir adanya kesalahan dan penyimpangan yang dilakukan oleh pelaksana dalam mengelola keuangan, maka diperlukan pihak lain yang bertugas mengaudit dari hasil proses yang telah dijalankan. Dalam hal audit internal yang dilaksanakan oleh Yayasan Masjid AlMaghfirah Surabaya, pengurus memiliki audit keuangan internal dan audit keuangan eksternal. Audit keuangan internal dilakukan selama empat kali dalam satu tahun yakni tiap triwulan dan semester dengan melibatkan pihak dewan pengurus, pihak dewan pengawas dan pihak dewan pembina yang dilakukan dalam bentuk rapat. Hal ini seperti yang dijelaskan oleh Ketua Umum Dewan Pengurus Masjid yakni, "Kalau audit itu sebenernya kita triwulan ada. Dari Dewan Pengawas interen tapi kalau dari ekstern setahun sekali. Itu di akhir. Nanti misalnya sekarang Desember selesai di audit di eksternal. Audit eksternal itu biasanya kita setelah membuat laporan tahunan. kalau internal kita kan triwulanan. Triwulan rapat kita selalu melibatkan dewan pengawas." ${ }^{\prime 34}$

Sehingga dari situ menunjukan bahwa pengaturan audit keuangan Yayasan Masjid Al-Maghfirah Surabaya sudah baik dengan adanya audit internal secara berkala tiap tiga bulan sekali. Selain itu juga menggunakan pihak eksternal untuk diaudit keuangannya.

\footnotetext{
33 Ibid.
}

\footnotetext{
34 H. Sudiro, Wawancara oleh Penulis, 13 November 2016, di Masjid Al-Magfirah, Surabaya.
} 
PERENCANAAN

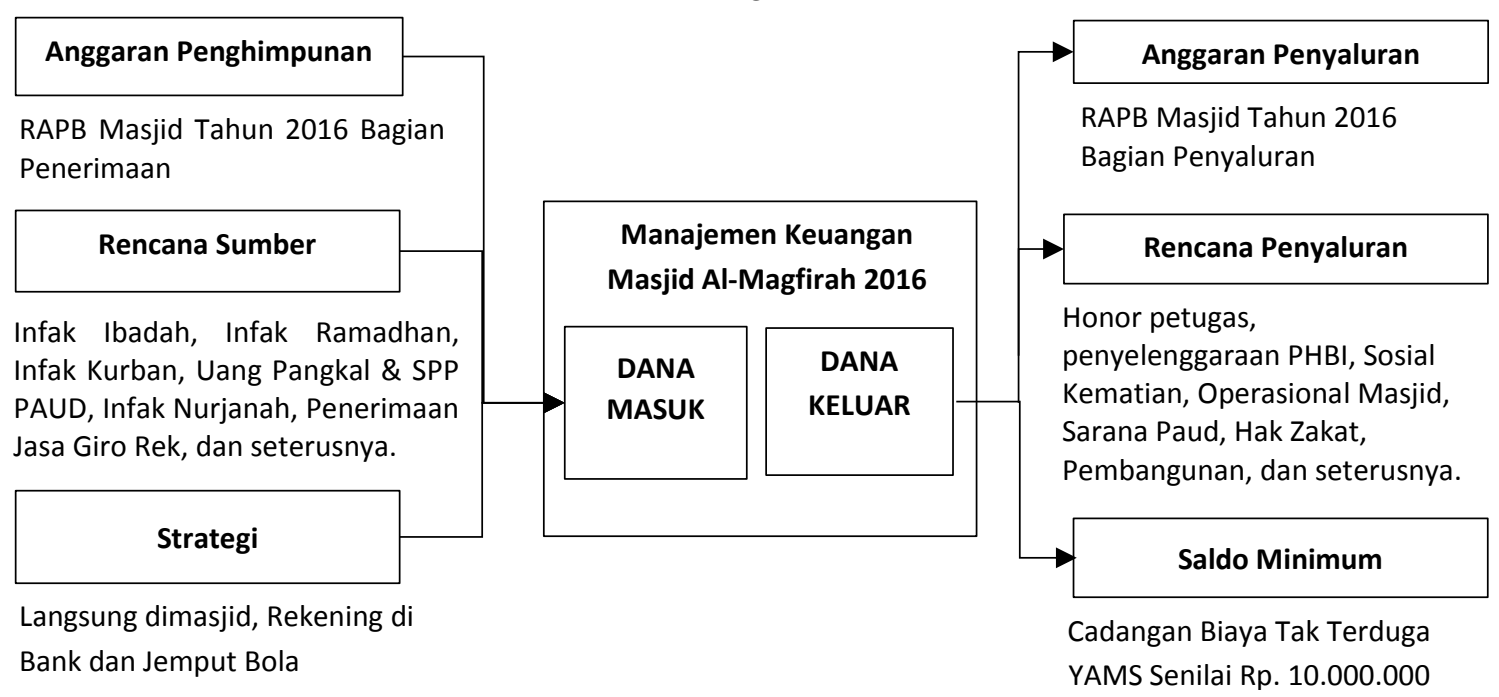

Gambar 1 - Sketsa Perencanaan Keuangan Masjid Al-Maghfirah Surabaya.

PENGELOLAAN

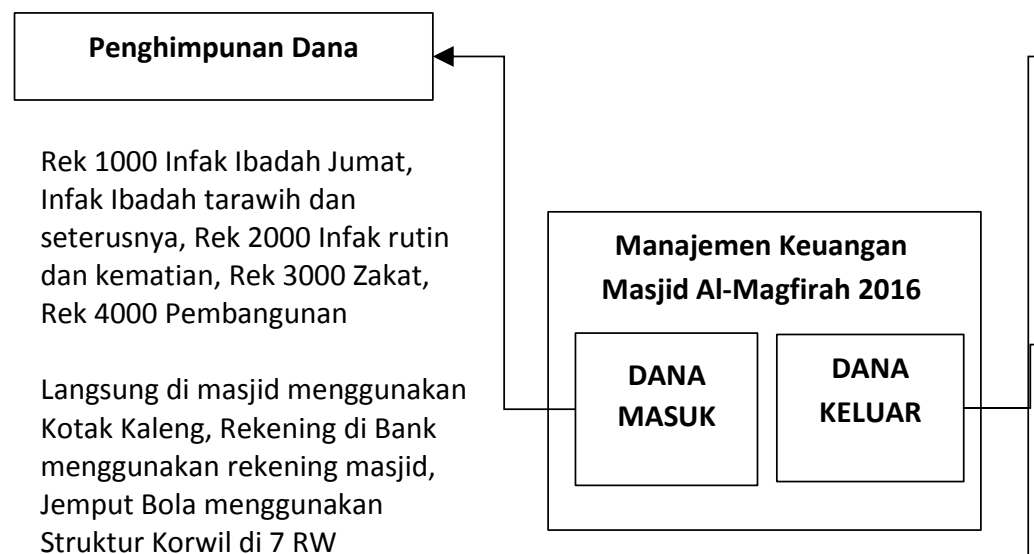

Struktur Korwil di 7 RW

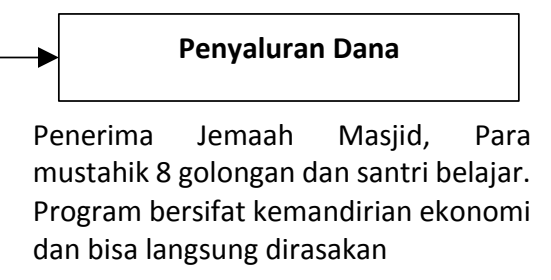

\section{Prosedur Pengeluaran Dana}

Pengguna adalah pengurus pelaksana program, Verifikator adalah pengurus Takmir pada rekening 1000 , pengurus DIR pada rekening 2000, pengurus DAZ pada rekening 3000 dan Ketua umum/I/II pada rekening 4000, Otorisator adalah Ketua Umum dewan Pengurus, dan kasir adalah bendahara masjid.

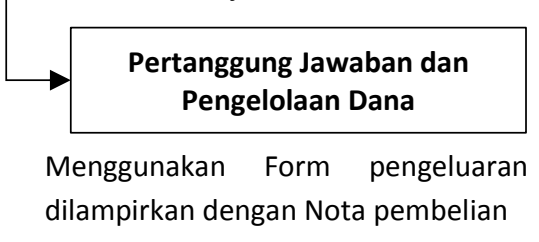

Gambar 2 - Sketsa Pengelolaan Keuangan Masjid Al-Maghfirah Surabaya. 
PENGENDALIAN

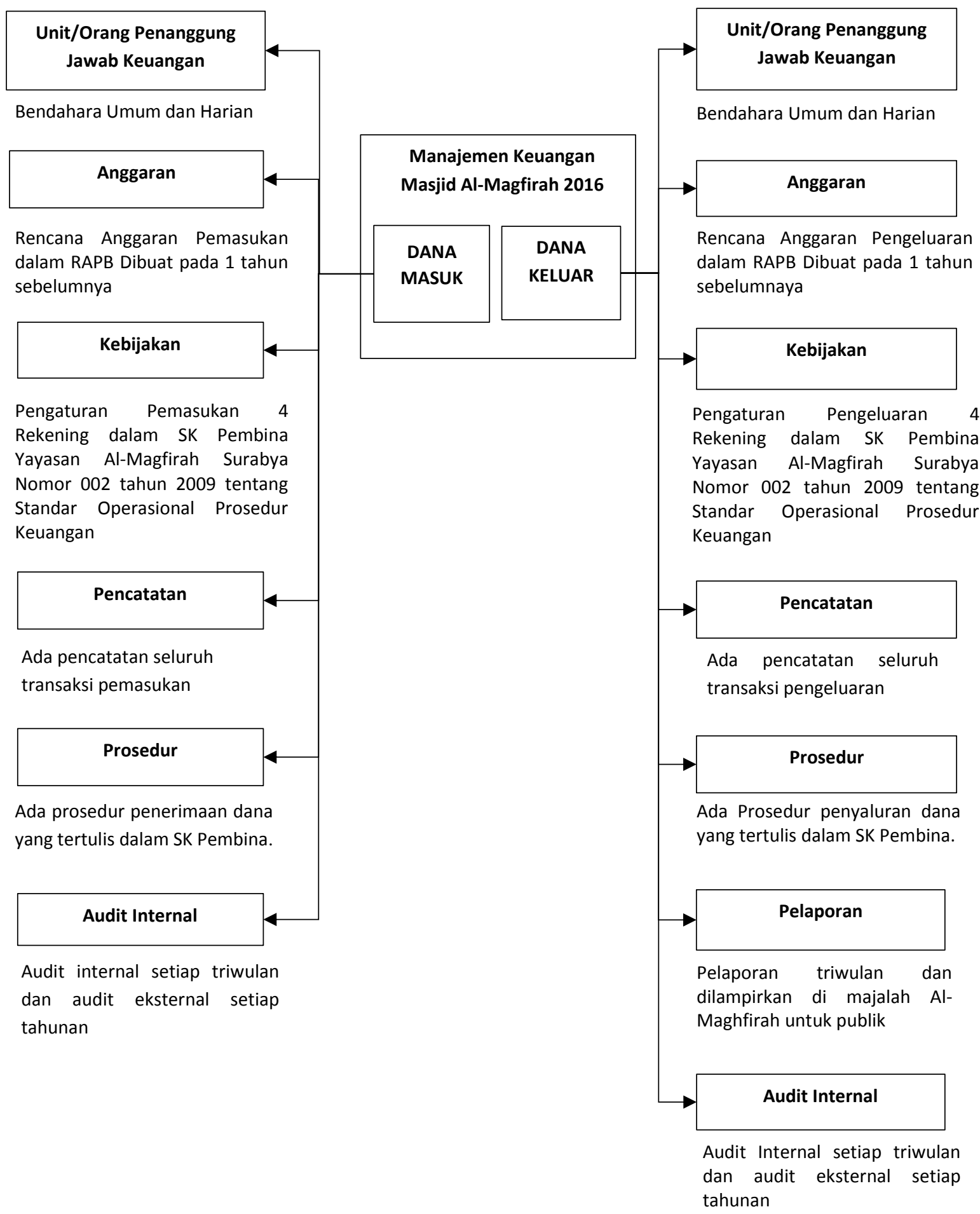

Gambar 3 - Sketsa Pengendalian Keuangan Masjid Al-Maghfirah Surabaya 


\section{Kesimpulan}

Dalam melakukan perencanaan keuangan, Yayasan Masjid Al-Maghfirah Surabaya menyusun rencana anggaran yang diterima dan dikeluarkan setiap satu tahun periode beserta rencana sumber-sumbernya dan rencana penyalurannya yang seluruhnya terangkum dalam Rencana Anggaran Penerimaan dan Belanja Yayasan Masjid AlMaghfirah Surabaya.

Dalam pengelolaan keuangan, sumbersumber dana yang didapat oleh masjid diklasifikasi berdasarkan karakteristik pemberiannya yang disimpan dalam empat jens rekening, yaitu rekening 1000 untuk takmir peribadahan; rekening 2000 untuk DIR dan pendidikan; rekening 3000 untuk ZIS; dan rekening 4000 untuk pembangunan. Metode penerimaannya pun ada yang diterima di masjid, jemput bola dan melalui transfer. Sedangkan untuk penyaluran dananya terdapat berbagai penerima dan bidang yang disalurkan masjid yang secara sifat ada yang bersifat konsumtif dan ada juga yang bersifat produktif.

Dalam melakukan pengendalian keuangan, Yayasan Masjid Al-Maghfirah Surabaya memenuhi seluruh aspek yang ada mulai dari adanya orang penanggung jawab keuangan, anggaran, kebijakan, pelaporan, pencatatan, prosedur dan audit internal. Masjid ini sangat mengedepankan untuk tertib dalam hal administrasi.

Dari kesimpulan tersebut menunjukan bahwa pada penerapan manajemen keuangan yang dilakukan oleh Yayasan Masjid Al-Maghfirah Surabaya terbilang sudah sangat baik. Dengan adanya pengelolaan keuangan yang baik tersebut selain dapat semakin meningkatkan kepercayaan dari para jemaah yang menyerahkan dana ZIS-nya kesana juga dapat menjadi inspirasi untuk masjid-masjid lain dalam hal mengelola keuangan.

\section{Blibliografi}

Ayub, Mohammad E. Manajemen Masjid. Jakarta: Gema Insani Press, 1996.

Badan Amil Zakat Nasional. "Statistik Zakat Nasional Tahun 2016." Baznas.go.id. Diakses 12 September, 2018. https://pid.baznas.go.id/wp-content/szn/SZN2016.pdf.

Departemen Agama Republik Indonesia. Al-Qur'an dan Terjemah. Jawa Barat: Cipta Bagus Segara, 2014.

Haq, Jerry Aulia Assadul, dan Dewi, Miranti Kartika. "Praktik Manajemen Keuangan Masjid dan Potensi Dana Masjid (Studi Kasus Pada Beberapa Masjid di Kota Bogor)." Accounting Departement, Faculty of Economic. University of Indonesia, 2013.

Ikatan Akutansi Indonesia. "Pernyataan Standar Akutansi Keuangan Pelaporan Keuangan Entitas Nirlaba Revisi 2011." Keuanganlsm.com. Diakses 18 Septermber 2018, http://keuanganlsm.com/finance/wp-content/uploads/PSAK-No.-45-PelaporanKeuangan-Entitas-Nirlaba-Revisi-2011.pdf. 
Ihsanuddin. "Raja Salman Terkejut Indonesia Punya 800.000 Masjid" Kompas.com. Diakses 12 September, 2018. https://nasional.kompas.com/read/2017/03/04/12144741/raja. salman.terkejut.indonesia.punya.800.000.masjid

Kabuhung, Merystika. "Sistem Informasi Akutansi Penerimaan dan Pengeluaran Kas Untuk Perencanaan dan Pengendalian Keuangan Pada Organisasi Nirlaba Keagamaan." Jurnal EMBA Vol. 1, No. 3, (2013).

Sochimin. "Praktik Manajemen Keuangan Masjid Berbasis Pemberdayaan Ekonomi Umat di Kota Purwokerto." Penelitian Individual, Institut Agama Islam Negeri Purwokerto, 2015.

Tanjung, Sri Indra Mulyati. "Tinjauan Ekonomi Islam Terhadap Manajemen Keuangan Lembaga Amil Zakat (LAZ) Al Azhar Peduli Ummat Dalam Mengelila Dana Zakat, Infak dan Shadaqah (ZIS)." Skripsi, Universitas Islam Negeri Syarifudin Hidayatullah, 2005.

Undang-Undang Republik Indonesia Nomor 16 Tahun 2001 tentang Yayasan, Pasal 37 ayat 1.

Widodo, Hertanto \& Teten Kustiwana. Akutansi \& Manajemen Keuangan Pengelola Zakat. Jakarta: Institut Manajemen Zakat, 2001. 